\title{
Pengaruh Harga Komoditi Pangan Terhadap Inflasi Di Kota Medan
}

\author{
Rahmanta $^{1^{*}}$ \\ Yusak Maryunianta ${ }^{2}$ \\ 1),2)Staf Pengajar Program Studi Agribisnis Fakultas Pertanian Universitas Sumatera Utara \\ email: rahmanta1213@gmail.com \\ Diterima: Maret 2020, Disetujui; April 2020, Dipublish: April 2020
}

\begin{abstract}
Abstrak
Inflasi sangat berpengaruh terhadap perekonomian suatu daerah. Inflasi dapat berdampak positif dan negatif, tergantung tinggi rendahnya inflasi tersebut. Apabila inflasi pada suatu daerah tinggi maka mempunyai pengaruh negatif, dimana perekonomian dirasakan lesu. Apabila inflasi pada suatu daerah rendah maka mempunyai pengaruh positif yang artinya dapat mendorong perekonomian menjadi lebih baik. Penelitian ini bertujuan untuk menganalisis berapa besar pengaruh perubahan harga pangan terhadap inflasi di Kota Medan. Data yang digunakan dalam penelitian ini adalah data time series periode Januari 2014 hingga Agustus 2019, data yang digunakan merupakan data sekunder berupa perkembangan harga pangan bulanan dan metode analisis data yang digunakan adalah Analisis VAR atau VECM. Hasil penelitian menunjukkan, dalam jangka pendek terdapat beberapa variabel yang mempengaruhi inflasi yaitu harga beras satu bulan sebelumnya, harga beras dua bulan sebelumnya, harga cabai merah satu bulan sebelumnya, harga cabai merah dua bulan sebelumnya, harga cabai rawit satu bulan sebelumnya, harga cabai rawit dua bulan sebelumnya, harga bawang merah dua bulan sebelumnya dan harga bawang putih dua bulan sebelumnya. Jangka panjang terdapat satu variabel yang mempengaruhi inflasi yaitu cabai merah.
\end{abstract}

Kata Kunci: inflasi, harga pangan dan VECM

\begin{abstract}
Inflation greatly affects the regional economy. It can be enlarge positively and negatively. When considering a high area it has negative influence, which is considered to have an influence. If in a low area, it must be something positive that can be encourage improvement for the better. This study aims to analyze the majority of changes in food prices to conversion in Medan. The data used in this study are time series data from January 2014 to August 2019, the data used are secondary data consisting of the development of monthly food prices and data analysis method used is VAR or VECM analysis. The result showed, in the short term inculding several variables that influence the price of rice one month earlier, the price of rice two months before, the price of red chili one month before, the price of red chili two months before, the price of cayenne pepper one month before, the price of cayenne pepper two month before, The price of onion two month before, the price of garlic two months before, one better variable length is a red chili.
\end{abstract}

Keyword: inflation, food prices, VECM

\section{PENDAHULUAN}

Fluktuasi harga komoditas pangan terjadi secara cepat. Adanya ketidakseimbangan antara permintaan dan penawaran pangan memerlukan suatu kebijakan stabilisasi harga pangan terdapat tiga keuntungan dari kebijakan stabilisasi harga pangan, yaitu: (1) melindungi petani selaku produsen dari penurunan harga sehingga petani dapat berlaku lebih efisien; (2) melindungi konsumen kelas menengah ke bawah 
yang berpendapatan rendah (poor consumers) dari gejolak peningkatan harga sehingga kebijakan ini dapat menjadi salah satu bentuk social safety net dan (3) menciptakan kondisi makro ekonomi yang lebih stabil sehingga mendorong investasi dan pertumbuhan ekonomi.

Bank Indonesia mengemukakan bahwa inflasi adalah kenaikan harga barang dan jasa secara umum, yang tinggi akan menjadi beban oleh banyak pihak. Ekonom aliran Keynesian berpendapat bahwa inflasi adalah suatu gejala moneter. Dalam kajian yang dipelopori Friedman dan dilanjutkan oleh berbagai kajian selanjutnya telah dapat menguji bahwa dalam jangka panjang terdapat keterkaitan yang erat antara inflasi dan jumlah uang yang beredar (Suseno, et al., 2009).

Menurunnya daya beli suatu mata uang akan berdampak menurun kepada kemampuan daya beli masyarakat untuk kebutuhan seharihari. Selain itu laju inflasi yang tidak stabil juga menyulitkan perencanaan bagi dunia usaha, tidak mendorong masyarakat untuk menabung, dan berbagai dampak negatif lain yang tidak kondusif bagi perekonomian secara keseluruhan.

Perubahan harga pada komoditas bahan pangan merupakan penyumbang terbesar laju inflasi Nasional, khususnya di daerah Kota Medan.Berdasarkan data yang diperoleh dari Badan Pusat Statistik (BPS) Kota Medan bahwa inflasi di Kota Medan tahun 2014 sebesar 8,24 $\%$, pada tahun 2015 sebesar 3,32 \%, pada tahun 2016 sebesar 6,6\%, dan pada tahun 2017 sebesar 3,18. Telah terjadi penurunan inflasi dari tahun ke tahun, tetapi kontribusi komoditi pangan terhadap inflasi di Kota Medan masih relatif tinggi.

Walaupun inflasi rendah tetapi secara statistik, inflasi lebih sering terjadi daripada deflasi artinya tiap bulan harga-harga produk yang dikonsumsi masyarakat terus mengalami kenaikan walaupun pertambahan kenaikannya tidak besar. Hanya saja jika terakumulasi dalam waktu yang lama, perubahan hargaharga tersebut akan terasa nyata dan besar bagi masyarakat luas.

$$
\text { Menurut Santoso }
$$
perubahan harga pada komoditas bahan pangan merupakan penyumbang terbesar laju inflasi di Indonesia, dengan jumlah penduduk yang cukup besar, permintaan bahan pangan pun semakin meningkat namun terkadang penawaran bahan pangan belum cukup memenuhi permintaan yang ada. Hal tersebut dapat meningkatkan harga bahan pangan yang akhirnya mendorong laju inflasi. Berdasarkan uraian diatas peneliti tertarik untuk meneliti pengaruh fluktuasi harga komiditi beras, cabai merah, cabai rawit dan bawang merah terhadap laju inflasi di Kota Medan. Hal ini didasari keempat komoditi ini memberikan kontribusi yang sangat dominan terhadap perkembangan inflasi di Kota Medan.

\section{METODE PENELITIAN}

\section{Teknik Pengumpulan Data}

Data yang digunakan dalam penelitian ini adalah data time series bulanan periode Januari 2014 hingga Agustus 2019. Data yang digunakan 
merupakan data sekunder berupa perkembangan harga pangan bulanan di tingkat konsumen yang merupakan ratarata harga di Kota Medan. Data tersebut diperoleh dari Badan Pusat Statistik (BPS) Kota Medan dan Sistem Harga Pangan Komoditas Utama Sumatera Utara (Siharapanku).

\section{Metode Analisis Data}

Metode yang digunakan adalah Vector Autoregressive (VAR). Analisis VAR dilakukan dengan menggunakan software Eviews 10. Komoditi pangan yang akan dianalisis yaitu harga beras, harga cabai merah, harga cabai rawit, harga bawang merah dan harga bawang putih di Kota Medan.

Berdasarkan model maka pengujian dengan menggunakan metode VAR dilakukan sesuai dengan persamaan sebagai berikut:

$$
\begin{aligned}
I N F_{t}= & a_{0}+a_{1} I N F_{t-p}+a_{2} H_{B B R}-p+a_{3} \\
& H_{t-p}+a_{4} H_{t-p}+a_{5} H_{t-p}+ \\
& a_{6} H_{t-p}+e_{t}
\end{aligned}
$$

HBR $_{\mathrm{t}}=\mathrm{b}_{0}+\mathrm{b}_{1}$ HBR $_{\mathrm{t}-\mathrm{p}}+\mathrm{b}_{2} \mathrm{INF}_{\mathrm{t}-\mathrm{p}}+\mathrm{b}_{3}$ $\mathrm{HCM}_{\mathrm{t}-\mathrm{p}}+\mathrm{b}_{4} \mathrm{HCR}_{\mathrm{t}-\mathrm{p}}+\mathrm{b}_{5} \mathrm{HBM}_{\mathrm{t}-\mathrm{p}}+$ $\mathrm{b}_{6} \mathrm{HBP}_{\mathrm{t}-\mathrm{p}}+\mathrm{et}_{2}$

$$
\begin{aligned}
\mathrm{HCM}_{\mathrm{t}}= & \mathrm{c}_{0}+\mathrm{c}_{1} \mathrm{HCM}_{\mathrm{t}-\mathrm{p}}+\mathrm{c}_{2} \mathrm{INF}_{\mathrm{t}-\mathrm{p}}+\mathrm{c}_{3} \\
& \mathrm{HBR}_{\mathrm{t}-\mathrm{p}}+\mathrm{c}_{4} \mathrm{HCR}_{\mathrm{t}-\mathrm{p}}+\mathrm{c}_{5} \mathrm{HBM}_{\mathrm{t}-\mathrm{p}}+ \\
& \mathrm{c}_{6} \mathrm{HBP}_{\mathrm{t}-\mathrm{p}}+\mathrm{et}_{3} \\
\mathrm{HCR}_{\mathrm{t}}= & \mathrm{d}_{0}+\mathrm{d}_{1} \mathrm{HCR}_{\mathrm{t}-\mathrm{p}}+\mathrm{d}_{2} \mathrm{INF}_{\mathrm{t}-\mathrm{p}}+\mathrm{d}_{3} \\
& \mathrm{HBR}_{\mathrm{t}-\mathrm{p}}+\mathrm{d}_{4} \mathrm{HCM}_{\mathrm{t}-\mathrm{p}}+\mathrm{d}_{5} \mathrm{HBM}_{\mathrm{t}-\mathrm{p}}+ \\
& \mathrm{d}_{6} \mathrm{HBP}_{\mathrm{t}-\mathrm{p}}+\mathrm{et}_{4}
\end{aligned}
$$

$\mathrm{HBM}_{\mathrm{t}}=\mathrm{e}_{0}+\mathrm{e}_{1} \mathrm{HBM}_{\mathrm{t}-\mathrm{p}}+\mathrm{e}_{2} \mathrm{INF}_{\mathrm{t}-\mathrm{p}}+\mathrm{e}_{3}$ HBRt-p $_{t}+\mathrm{e}_{4} \mathrm{HCM}_{\mathrm{t}-\mathrm{p}}+\mathrm{e}_{5} \mathrm{HCM}_{\mathrm{t}-\mathrm{p}}+$ $\mathrm{e}_{6} \mathrm{HBP}_{\mathrm{t}-\mathrm{p}}+\mathrm{et}_{5}$

$\mathrm{HBP}_{\mathrm{t}}=\mathrm{f}_{0}+\mathrm{f}_{1} \mathrm{HBP}_{\mathrm{t}-\mathrm{p}}+\mathrm{f}_{2} \mathrm{INF}_{\mathrm{t}-\mathrm{p}}+\mathrm{f}_{3}$ $\mathrm{HBR}_{\mathrm{t}-\mathrm{p}}+\mathrm{f}_{4} \mathrm{HCM}_{\mathrm{t}-\mathrm{p}}+\mathrm{f}_{5} \mathrm{HCR}_{\mathrm{t}-\mathrm{p}}+$ $\mathrm{f}_{6} \mathrm{HBM}_{\mathrm{t}-\mathrm{p}}+\mathrm{et}_{6}$

Dimana :

$\mathrm{INF}_{\mathrm{t}}=$ Inflasi pada tahun sekarang

$\begin{aligned} \mathrm{INF}_{\mathrm{t}-\mathrm{p}}= & \begin{array}{l}\text { Inflasi pada tahun } \\ \text { sebelumnya }\end{array} \\ \mathrm{HBR}_{\mathrm{t}}= & \begin{array}{l}\text { Harga beras pada tahun } \\ \text { sekarang }\end{array} \\ \mathrm{HBR}_{\mathrm{t}-\mathrm{p}}= & \begin{array}{l}\text { Harga beras pada tahun } \\ \text { sebelumnya }\end{array} \\ \mathrm{HCM}_{\mathrm{t}}= & \text { Harga cabe merah pada } \\ & \text { tahun sekarang } \\ \mathrm{HCM}_{\mathrm{t}-\mathrm{p}}= & \text { Harga cabe merah pada } \\ & \text { tahun sebelumnya } \\ \mathrm{HCR}_{\mathrm{t}}= & \text { Harga cabe rawit pada } \\ & \text { tahun sekarang } \\ \mathrm{HCR}_{\mathrm{t}-\mathrm{p}}= & \text { Harga cabe rawit pada } \\ & \text { tahun sebelumnya } \\ \mathrm{HBM}_{\mathrm{t}}= & \begin{array}{l}\text { Harga bawang merah pada } \\ \text { tahun sekarang }\end{array} \\ \mathrm{HBM}_{\mathrm{t}-\mathrm{p}}= & \begin{array}{l}\text { Harga bawang merah pada } \\ \text { tahun sebelumnya }\end{array} \\ \mathrm{HBP}_{\mathrm{t}}= & \text { Harga bawang putih pada } \\ \text { tahun sekarang } & \text { Harga bawang putih pada } \\ \mathrm{HBP}_{\mathrm{t}-\mathrm{p}}= & \text { Kahun sebelumnya } \\ \mathrm{a}_{0} \ldots \mathrm{f}_{6}= & \text { Koefisien } \\ \mathrm{a}_{1} \ldots \mathrm{f}_{6}= & \text { Error term } \\ \mathrm{et}_{1} \ldots \mathrm{et} 6 \mathrm{f} & =\end{aligned}$

Tahapan Model Vector Autoregressive (VAR)

Spesifikasi model VAR meliputi pemilihan variabel dan penentuan lag setiap variabel endogen. Terdapat beberapa tahapan dalam melakukan analisis VAR, yaitu: (1) Uji Stasioneritas Data; (2) Uji Stabilitas Model VAR; (3) Uji Kointegrasi; (4) Estimasi Vector Error Corection Model (VECM); (5) Analisis Impulse Response Function (IRF); dan (6) Analisis Forecast Error Variance Decomposition (FEVD). 


\section{HASIL DAN PEMBAHASAN}

\section{Uji Stasioneritas Data}

Berdasarkan hasil uji stasioneritas pada variabel inflasi, beras, cabe merah, cabe rawit, bawang merah dan bawang putih dimana semua variabel mengalami stationer artinya memiliki nilai rata-rata dan varians yag konstan sepanjang waktu, hal ini ditunjukkan nilai ADF statistic pada semua variabel lebih kecil daripada MacKinnon critical value, maka tolak $\mathrm{H}_{0}$ yang artinya stasioner.

\section{Uji Stabilitas Model VAR}

Berdasarkan Tabel 1 diketahui bahwa nilai modulus seluruh akar unit $<1$ maka dapat disimpulkan bahwa spesifikasi model stabil, sehingga estimasi VAR yang ada digunakan untuk analisis Impulse Response Function (IRF) dan Analisis Forecast Error Variance Decomposition (FEVD) stabil dan valid. Dan seluruh akar-akar unit hasil pengujian stabilitas estimasi VAR memiliki modulus lebih kecil dari satu.

Tabel 1. Hasil Uji Stabilitas VAR Kota Medan

\begin{tabular}{|c|c|}
\hline Root & Modulus \\
\hline$-0.214383-0.553707 \mathrm{i}$ & 0.593760 \\
\hline$-0.214383+0.553707 \mathrm{i}$ & 0.593760 \\
\hline$-0.038948-0.587652 \mathrm{i}$ & 0.588941 \\
\hline$-0.038948+0.587652 \mathrm{i}$ & 0.588941 \\
\hline $0.213184-0.534917 \mathrm{i}$ & 0.575833 \\
\hline $0.213184+0.534917 \mathrm{i}$ & 0.575833 \\
\hline 0.535935 & 0.535935 \\
\hline $0.308022-0.367969 \mathrm{i}$ & 0.479874 \\
\hline $0.308022+0.367969 \mathrm{i}$ & 0.479874 \\
\hline-0.472093 & 0.472093 \\
\hline-0.385981 & 0.385981 \\
\hline-0.092429 & 0.092429 \\
\hline$-0.214383-0.553707 \mathrm{i}$ & 0.593760 \\
\hline$-0.214383+0.553707 \mathrm{i}$ & 0.593760 \\
\hline
\end{tabular}

Sumber: Data diolah dengan Eviews10

\section{Uji Kointegrasi}

Berdasarkan hasil Tabel 2 menunjukkan adanya kointegrasi pada Uji Johansen Cointegration Test memperlihatkan indikasi awal hubungan jangka panjang antar variabel (cointegrated) sehingga antar variabel tersebut membentuk suatu hubungan yang linear. Hasil uji kointegrasi menunjukkan bahwa variabel inflasi, harga beras, harga cabe merah, harga cabe rawit, harga bawang merah, harga bawang putih memiliki hubungan jangka panjang. 
Tabel 2. Hasil Johansen Cointegration Test

\begin{tabular}{|c|c|c|c|c|}
\hline $\begin{array}{l}\text { Hypothesized } \\
\text { No. of CE(s) }\end{array}$ & Eigenvalue & $\begin{array}{l}\text { Trace } \\
\text { Statistic }\end{array}$ & $\begin{array}{l}0.05 \\
\text { Critical } \\
\text { Value } \\
\end{array}$ & Prob.** \\
\hline None* & 0.645887 & 208.1066 & 95.75366 & 0.0000 \\
\hline At most $1 *$ & 0.555318 & 145.8182 & 69.81889 & 0.0000 \\
\hline At most $2 *$ & 0.498358 & 97.19449 & 47.85613 & 0.0000 \\
\hline At most $3 *$ & 0.359704 & 55.80240 & 29.79707 & 0.0000 \\
\hline At most $4 *$ & 0.274548 & 29.05290 & 15.49471 & 0.0003 \\
\hline At most $5 *$ & 0.150625 & 9.795245 & 3.841466 & 0.0017 \\
\hline
\end{tabular}

Sumber: Data diolah dengan Eviews10

\section{Estimasi Vector Error Corection Model (VECM)}

Pengujian signifikan pada hasil estimasi dilakukan dengan cara membandingkan nilai t-hitung > nilai t- tabel maka dapat dikatakan memiliki pengaruh yang signifikan dan sebaliknya jika nilai t-hitung < nilai t-tabel maka dapat dikatakan memiliki pengaruh yang tidak signifikan.

Tabel 3. Hasil Estimasi VECM Kota Medan

\begin{tabular}{|l|l|l|l|l|}
\hline Variabel & Koefisien & T-Statistik & T-Tabel (5\%) & Intepretasi \\
\hline \multicolumn{5}{|c|}{ Jangka Pendek } \\
\hline CointEq1 & -0.277596 & {$[-2.71932]$} & - & \\
\hline D(INF(-1)) & -0.361241 & {$[-2.28801]$} & 1.67155 & Tidak Signifikan \\
\hline D(INF(-2)) & -0.258974 & {$[-1.82614]$} & 1.67155 & Tidak Signifikan \\
\hline D(HBR(-1)) & -0.018874 & {$[-0.31538]$} & 1.67155 & Signifikan \\
\hline D(HBR(-2)) & -0.024271 & {$[-0.64730]$} & 1.67155 & Signifikan \\
\hline D(HCM(-1)) & 0.005318 & {$[1.25588]$} & 1.67155 & Signifikan \\
\hline D(HCM(-2)) & 0.006204 & {$[1.59017]$} & 1.67155 & Signifikan \\
\hline D(HCR(-1)) & 0.003161 & {$[0.74296]$} & 1.67155 & Signifikan \\
\hline D(HCR(-2)) & 0.002183 & {$[0.54804]$} & 1.67155 & Signifikan \\
\hline D(HBM(-1)) & 0.016243 & {$[2.19114]$} & 1.67155 & Tidak Signifikan \\
\hline D(HBM(-2)) & 0.008803 & {$[1.53833]$} & 1.67155 & Signifikan \\
\hline D(HBP(-1)) & -0.024026 & {$[-2.63059]$} & 1.67155 & Tidak Signifikan \\
\hline D(HBP(-2)) & -0.012502 & {$[-1.46165]$} & 1.67155 & Signifikan \\
\hline C & 0.006667 & {$[0.06556]$} & 1.67155 & Signifikan \\
\hline & & Jangka Panjang & \\
\hline INF(-1) & 1.000000 & - & - & - \\
\hline HBR(-1) & -0.335643 & {$[-3.30125]$} & 1.67155 & Tidak Signifikan \\
\hline HCM(-1) & -0.006867 & {$[-0.81905]$} & 1.67155 & Signifikan \\
\hline HCR(-1) & 0.022320 & {$[1.82537]$} & 1.67155 & Tidak Signifikan \\
\hline HBM(-1) & 0.098452 & {$[6.94548]$} & 1.67155 & Tidak Signifikan \\
\hline HBP(-1) & -0.075863 & {$[-4.26955]$} & 1.67155 & Tidak Signifikan \\
\hline C & -0.576712 & - & - & - \\
\hline Sumber : Data & & &
\end{tabular}

Sumber : Data diolah dengan Eviews 10 
Hasil estimasi VECM diatas menunjukkan bahwa interpretasi dari nilai error correction (CoeintEq1) bernilai negatif sebesar -0.277596 sehingga model error correction (CoeintEq1) dinyatakan bahwa terdapat penyesuaian dari jangka pendek ke jangka panjang pada inflasi di Kota Medan sebesar $0.2776 \%$ untuk setiap bulannya.

Berdasarkan hasil pada Tabel 4 dapat diketahui bahwa pada jangka pendek terdapat beberapa variabel yang mempengaruhi inflasi yaitu harga beras bulan lalu, harga beras dua bulan lalu, harga cabe merah bulan lalu, harga cabe merah dua bulan lalu, harga cabe rawit bulan lalu, harga cabe rawit dua bulan lalu, harga bawang merah dua bulan lalu, dan harga bawang putih dua bulan lalu. Sedangkan pada jangka panjang terdapat satu variabel yang mempengaruhi inflasi yaitu harga cabe merah. Variabel-variabel tersebut dikatakan memiliki pengaruh yang signifikan terhadap inflasi karena nilai tstatistik masing-masing variabel tersebut lebih besar dari t-tabel.

Hal ini sesuai dengan hasil penelitian Setiawan (2015), bahwa fluktuasi harga beras memiliki pengaruh terhadap keragaman inflasi di Provinsi Banten. Hal ini dikarenakan beras merupakan makanan pokok utama masyarakat di Indonesia, sehingga kenaikan harga beras tentu tidak akan menurunkan konsumsi beras di masyarakat.

Hasil penelitian ini sesuai dengan Rizaldy (2017) dimana harga bawang merah berpengaruh signifikan terhadap inflasi di Kota Malang.
Dengan demikian inflasi harga pangan pada jangka panjang maupun jangka pendek tetap menjadi pendorong yang signifikan untuk inflasi harga konsumen secara keseluruhan dan harga pangan di Kota Medan.

Hasil estimasi VECM sampai lag-2 untuk periode pengamatan Januari 2014 sampai Agustus 2019, model VECM untuk variabel inflasi (INF), harga beras (HBR), harga cabai merah (HCM), harga cabai rawit (HCR), harga bawang merah (HBM), dan harga bawang putih (HBP) sesuai dengan persamaan VECM jangka pendek adalah sebagai berikut :

$$
\begin{aligned}
& \mathrm{D}(\mathrm{INF})=0.006667-0.018874\left(\mathrm{HBR}_{(\mathrm{t}-1)}\right) \\
& -0.024271\left(\operatorname{HBR}_{(\mathrm{t}-2)}\right)+0.005318 \\
& \left(\operatorname{HCM}_{(\mathrm{t}-1)}\right)+0.006204\left(\operatorname{HCM}_{(\mathrm{t}-2)}\right)+ \\
& 0.003161\left(\mathrm{HCR}_{(\mathrm{t}-1))}+0.002183\right. \\
& \left(\operatorname{HCR}_{(\mathrm{t}-2)}\right)+0.016243\left(\operatorname{HBM}_{(\mathrm{t}-1)}\right)+ \\
& \left.0.008803 \operatorname{lHBM}_{(\mathrm{t}-2)}\right)-0.024026 \\
& \left(\operatorname{HBP}_{(\mathrm{t}-1)}\right)-0.012502\left(\operatorname{HBP}_{(\mathrm{t}-2)}\right)
\end{aligned}
$$

Adapun persamaan VECM untuk jangka panjang adalah sebagai berikut :

$$
\begin{aligned}
\text { INF }= & -0.576712-0.335643 \operatorname{HBR}_{(\mathrm{t}-1)}- \\
& 0.006867 \operatorname{HCM}_{(\mathrm{t}-1)}+0.022320 \\
& \operatorname{HCR}_{(\mathrm{t}-1)+0.098452 \operatorname{HBM}_{(\mathrm{t}-1)}-} \\
& 0.075863 \operatorname{HBP}_{(\mathrm{t}-1)}
\end{aligned}
$$

\section{Analisis Impulse Response Function (IRF)}

Hasil uji IRF akan ditampilkan dalam bentuk tabel yang dijelaskan dalam jangka waktu 36 periode ke depan dari periode penelitian. Kemudian akan dilihat dalam tiga periode jangka waktu yaitu jangka pendek (1-12), jangka menengah (bulan ke-13 sampai ke-24) dan jangka panjag (bulan ke-25 sampai ke-36). 
Tabel 4. Hasil IRF

\begin{tabular}{|l|c|c|c|c|c|c|}
\hline No. & INF & HBR & HCM & HCR & HBM & HBP \\
\hline 1 & 0.785074 & 0.000000 & 0.000000 & 0.000000 & 0.000000 & 0.000000 \\
\hline 12 & 0.368194 & 0.096418 & 0.180530 & -0.091559 & -0.174863 & 0.030296 \\
\hline 13 & 0.366182 & 0.098286 & 0.184103 & -0.091960 & -0.177624 & 0.034830 \\
\hline 24 & 0.367570 & 0.098256 & 0.182027 & -0.090900 & -0.175608 & 0.033764 \\
\hline 25 & 0.367581 & 0.098243 & 0.182015 & -0.090789 & -0.175555 & 0.033768 \\
\hline 36 & 0.367573 & 0.098227 & 0.181998 & -0.090814 & -0.175548 & 0.033729 \\
\hline
\end{tabular}

Sumber : Data diolah dengan Eviews10

Berdasarkan Tabel 4 hasil IRF untuk jangka pendek bahwa setiap satu standar deviasi terjadi shock inflasi akan direspon inflasi itu sendiri hingga naik sebesar 0.368194. Hasil IRF yang memberikan respon yang besar terhadap inflasi yaitu harga cabai merah. Setiap satu standar deviasi terjadi shock selisih harga cabai merah akan direspon oleh inflasi hingga naik 0.180530 yang berarti jika kenaikan selisih harga cabai merah sebesar $1 \%$ akan mengakibatkan kenaikan inflasi sebesar $0.180530 \%$.

Pada jangka menengah bahwa setiap satu standar deviasi terjadi shock inflasi akan direspon inflasi itu sendiri hingga naik sebesar 0.367570 . Hasil IRF yang memberikan respon yang besar terhadap inflasi yaitu harga cabai merah. Setiap satu standar deviasi terjadi shock selisih harga cabai merah akan direspon oleh inflasi hingga naik 0.182027 yang berarti jika kenaikan selisih harga cabai merah sebesar $1 \%$ akan mengakibatkan kenaikan inflasi sebesar $0.182027 \%$.

$$
\text { Pada jangka panjang bahwa }
$$
setiap satu standar deviasi terjadi shock inflasi akan direspon inflasi itu sendiri hingga naik sebesar 0.367573. Hasil IRF yang memberikan respon yang besar terhadap inflasi yaitu harga cabai merah. Setiap satu standar deviasi terjadi shock selisih harga cabai merah akan direspon oleh inflasi hingga naik 0.181998 yang berarti jika kenaikan selisih harga cabai merah sebesar $1 \%$ akan mengakibatkan kenaikan inflasi sebesar 0.181998\%.

\section{Analisis Forecast Error Variance Decomposition (FEVD)}

Tabel 5. Analisis Forecast Error Variance Decomposition (FEVD)

\begin{tabular}{|l|c|c|c|c|c|c|c|}
\hline $\begin{array}{l}\text { Peri } \\
\text { ode }\end{array}$ & S.E. & INF & HBR & HCM & HCR & HBM & HBP \\
\hline 1 & 0.785074 & 100.0000 & 0.000000 & 0.000000 & 0.000000 & 0.000000 & 0.000000 \\
\hline 12 & 1.751703 & 66.74360 & 3.609130 & 13.41639 & 3.386505 & 12.04708 & 0.797296 \\
\hline 13 & 1.813098 & 66.37893 & 3.662701 & 13.55420 & 3.418287 & 12.20476 & 0.781117 \\
\hline 24 & 2.384704 & 64.50734 & 3.986655 & 14.24417 & 3.572755 & 13.01604 & 0.673047 \\
\hline 25 & 2.430003 & 64.41293 & 4.002861 & 14.27910 & 3.580385 & 13.05722 & 0.667499 \\
\hline 36 & 2.881632 & 63.70249 & 4.124570 & 14.54172 & 3.638541 & 13.36733 & 0.625342 \\
\hline
\end{tabular}

Sumber : Data diolah dengan Eviews10 
Berdasarkan Tabel 5 hasil analisis FEVD komoditas yang paling dominan dalam menjelaskan keragaman inflasi di Kota Medan dari yang paling besar pengaruhnya ke yang paling kecil adalah harga cabai merah, harga bawang merah, harga beras, harga cabe rawit, dan harga bawang putih.

Cabai merah menempati urutan pertama dalam menjelaskan keragaman inflasi di Kota Medan dengan persentase sebesar $14.541 \%$. Tingginya permintaan masyarakat terhadap cabai diduga karena belum ada komoditi atau bahan pangan yang dapat mensubtitusi kebutuhan cabai merah. Tidak hanya untuk konsumsi pangan sehari-hari, cabai merah juga digunakan untuk bahan baku dalam industry makanan. Dengan demikian nilai konsumsi cabai merah di Kota Medan relatif besar. Oleh karena itu, naiknya harga cabai merah akan menyebabkan keragaman inflasi di Kota Medan.

Cabai merah dapat digunakan dalam bentuk segar maupun olahan. Cabai merah dalam bentuk segar dapat digunakan sebagai bumbu masakan dan sambal. Sedangkan dalam bentuk olahan diiolah menjadi saos sambal dan bubuk cabai.

Bawang merah dan beras merupakan komoditi yang menempati urutan ke-2 dan ke-3 dalam menjelaskan keragaman inflasi di di Kota Medan dengan persentase sebesar 13.367\% dan 4.124\%. Bawang merah digunakan sebagai bumbu masakan, bahan pelengkap untuk makanan maupun obat-obatan. Sedangkan beras merupakan makanan pokok utama sehari-hari masyarakat pada umumnya, termasuk Kota Medan. Namun persentasenya dalam menjelaskan keragaman inflasi tidak terlalu tinggi. Hal ini diduga bahwa kebutuhan konsumsi beras di Kota Medan tidak bertambah secara signifikan walaupun jumlah penduduk terus meningkat karena konsumsi beras per kapita menurun. Penurunan konsumsi komoditi beras per kapita didorong oleh perubahan selera masyarakat seiring dengan peningkatan pendapatan sehingga masyarakat lebih banyak mengkonsumsi seperti roti dan makanan lainnya.

Harga cabai rawit dan harga bawang putih merupakan komoditi yang menempati urutan ke-4 dan ke-5 dalam menjelaskan keragaman inflasi di Kota Medan dengan persentase sebesar $3.638 \%$ dan $0.625 \%$. Harga cabai rawit dan harga bawang putih adalah bumbu masakan, bahan pelengkap untuk makanan maupun obat-obatan.

\section{Hasil penelitian ini sesuai} Setiawan (2015) dimana hasil analisis VAR menunjukkan bahwa dalam jangka pendek hanya komoditas cabai merah kriting yang berdampak secara signifikan terhadap inflasi di Provinsi Banten. Pada jangka panjang terdapat enam komoditas yang berdampak secara signifikan terhadap inflasi di Provinsi Banten, yaitu daging sapi murni, jagung, beras, daging ayam ras, telur yam ras serta cabai merah keriting.

\section{SIMPULAN}

Jangka pendek terdapat beberapa variabel yang mempengaruhi inflasi yaitu harga beras satu bulan sebelumnya, harga beras dua bulan 
sebelumnya, harga cabai merah satu bulan sebelumnya, harga cabai merah dua bulan sebelumnya, harga cabai rawit satu bulan sebelumnya, harga cabai rawit dua bulan sebelumnya, harga bawang merah dua bulan sebelumnya dan harga bawang putih dua bulan sebelumnya. Sedangkan pada jangka panjang terdapat satu variabel yang mempengaruhi inflasi yaitu cabai merah. Variabel tersebut memiliki pengaruh yang signifikan terhadap inflasi karena nilai t-statistik masingmasing variabel tersebut lebih besar dari t-tabel. Hasil analisis FEVD komoditas yang paling dominan dalam menjelaskan keragaman inflasi di Kota Medan dari yang paling besar pengaruhnya ke yang paling kecil adalah harga cabai merah, harga bawang merah, harga beras, harga cabe rawit, dan harga bawang putih.

\section{UCAPAN TERIMA KASIH}

Kami mengucapkan terima kasih kepada Lembaga Penelitian Universitas Sumatera Utara yang telah berkontribusi secara moral dan material sebagai lembaga yang telah mendanai penelitian ini melalui skema Penelitian Dasar dengan kontrak Nomor: 351/UN5.2.3.1/PPM/KP-TALENTA USU/2019.

\section{DAFTAR PUSTAKA}

Andryas, T. 2015. Analisis Inflasi dengan Pendekatan Panel Dinamis: Studi Kasus di Kawasan Jawa, Sumatera Utara, Sumatera Selatan, Sulawesi Selatan, Kalimantan Selatan, dan Bali. Jurnal Ekonomi dan Bisnis, Tahun XXVI, No. 3 Desember 2015. Jakarta.
Badan Pusat Statistik Kota Medan, 2018. Data Inflasi Tahun 2014-2018. Kota Medan.

Badan Pusat Statistik Kota Medan, 2018. Medan Dalam Angka Tahun 2018. Kota Medan.

Badan Pusat Statistik Sumatera Utara. 2018. Inflasi Kumulatif Kota di Sumatera Utara 1980 - 2016. Medan.

BI, $2018 . \quad$ Inflasi. https://www.bi.go.id/id/moneter/i nflasi/pengenalan/Contents/Defaul t.aspx

Desmayanti, J. dkk. 2017. Analisis Variasi Harga Beras di Provinsi Riau dan Daerah Pemasok. Jurnal Dinamika Pertanian, Vol XXXIII No. 2 Agustus 2017.

Hasanah, F. N. 2014. Dampak Fluktuasi Harga Pangan Hewani Asal Ternak terhadap Inflasi di Kabupaten Bogor. Bogor.

Jogwanich, J. and Park, D. 2009. Inflation in Developing Asia. Journal of Asian Economics

Nurmapika, R. ddk. 2018. Analisis Volatilitas Harga Komoditas Pangan Strategis di Provinsi Kalimantan Barat. Jurnal Socia Economic of Agriculture, Volume 7, Nomor 1 April 2018.

Prabowo, D.W. 2014. Pengelompokan Komoditi Bahan Pangan Pokok Dengan Metode Analitycal Hierarchy Process. Jurnal Ilmiah: Pusat Kebijakan Perdagangan Dalam Negeri. Jakarta.

Rizaldy, D. Z. 2017. Pengaruh Harga Komoditas Pangan Terhadap Inflasi Di Kota Malang Tahun 2011-2016. Jurnal Ekonomi Pembangunan, Vol. 15, No. 2, hlm: 172.

Santoso, T. 2011. Aplikasi Model GARCH pada Data Inflasi Bahan Makanan Indonesia. Jurnal Organisasi dan 
Manajemen, Vol. 7, Nomor 1, hlm: 38-52.

Setiawan, A. F. 2015. Fluktuasi Harga Komoditas Pangan dan Dampaknya terhadap Inflasi di Provinsi Banten. Intitut Pertanian Bogor. Bogor.

Suseno dan Siti Aisyah. 2009. Inflasi. Seri Kebangsentralan.

Pendidikan dan Studi Kebangsentralan (PPSK) Bank Indonesia, Jakarta.

Vivy, K. 2018. Analisis Pengaruh Indeks Harga Konsumen Terhadap Inflasi di Kota Palangka Raya dan Kabupaten Sampit. Jurnal Aplikasi Manajemen Ekonomi dan Bisnis. Vol. 3 No. 1 Oktober 2018.

Zhang, C., Chunming M, and Lisa G. 2014. Food Price and Inflation Dynamics in China. Emeraldinsight, China Agricultural Economic Review Vol. 6 No. 3, 2014 pp. 395- 412, 1756-137X DOI 10.1108/CAER12-2012-0140. 